\title{
A Case of Hypertrophic Pachymeningitis presenting with Hearing Loss and Facial Nerve Palsy
}

\author{
Yoshihiro Chiba ${ }^{1)}$, Toshiyuki Kokatsu ${ }^{1)}$ and Nobuhiko Oridate ${ }^{2)}$
}

\begin{abstract}
Hypertrophic pachymeningitis (HP) is a rare disease and patients with HP present with headache and multiple cranial nerve palsy. We report herein on a case of $\mathrm{HP}$ with hearing loss and facial palsy. A 61-yearold woman presented with headache, right hearing loss, right facial palsy and numbness of the right chin. She was first diagnosed as having severe acute otitis media. Most of the symptoms persisted after treatment with antibiotics and corticosteroids. Ga-DTPA-enhanced magnetic resonance imaging (MRI) revealed diffuse thickening of the dura mater consistent with HP. HP is caused by several diseases such as infection, collagen disease, vasculitis syndrome, IgG4 related disease, and metastatic cancer. In this case, HP was caused by metastatic rectal cancer to the cranial bone and dura mater. The facial palsy and chin numbness improved after the chemoradiotherapy, whereas hearing loss did not. HP should be taken into consideration when multiple cranial nerve palsy are observed. Ga-DTPA-enhanced MRI is useful in the diagnosis of HP.
\end{abstract}

Keywords : hypertrophic pachymeningitis, hearing loss, facial nerve palsy, otitis media, numb chin syndrome

\section{References}

1）深美 悟, 春名眞一, 平林秀樹, 他：耳症状で初発し肥厚 性硬膜炎を合併した Wegener 肉芽腫症疑い例. Otol Jpn 20： 173-179, 2010.

2) 陸 重雄, 橋詰良夫, 吉田眞理, 他: 肥厚性硬膜炎は「IgG4 関連疾患」か? 臨神経 49: 594-596, 2009.

3）藤崎俊之, 和田匡史, 壁谷雅之, 他：一側性進行性感音難 聴を呈した特発性肥厚性脳硬膜炎の 1 症例. Audiol Jpn 45: 306-311, 2002.

4) 留守卓也, 堀口茂俊, 岡本美孝: 肥厚性硬膜炎により両側 第 VII ・VIII 脳神経・外眼筋障害をきたした一症例. Audiol Jpn 48: 575-576, 2005.

5）石山賢一, 岡田睦実, 安齋尚之, 他: 肥厚性硬膜炎様の神経 症状で発症したマントル細胞リンパ腫. 臨血. 52: 1788-1793, 2011.

6）植田晃広, 上田真努香, 三原貴照, 他：肥厚性硬膜炎の臨 床像とステロイド治療法に関する 1 考察 : 自験 3 症例と文 献例 66 症例からの検討. 臨神経 51：243-247, 2011.

7) Bang OY, Kim DI, Yoon SR, et al. : Idiopathic hypertrophic pachymeningeal lesions: correlation between clinical patterns and neuroimaging characteristics. Eur Neurol 39: 49-56, 1998.

8）村上信五, 木口 淳, 山野耕嗣, 他 : 急性 - 慢性中耳炎に よる顔面神経麻痺. Otol Jpn 14: 51-54, 2004.

9）坂本裕史, 菅 充生, 千葉 進, 他 : Numb chin syndrome を呈した肝細胞癌の 1 例. 肝臓 34: 740-746, 1993.

10） 中谷幸太郎, 糟谷英俊, 清水 隆, 他: 滲出性中耳炎として 治療されていた肥厚性硬膜炎の 1 例. 東女医大誌 69：688693, 1999.

11）福留真二, 河野浩万, 烏原康治, 他 : 難聴を伴った肥厚性 硬膜炎の 1 例. Audiol Jpn 46：491-492, 2003.

12）阿曾沼祥, 鈴木陽子, 畠山 明, 他：肥厚性硬膜炎による 多彩な中枢神経症状を呈した Wegener 肉芽腫症の 1 例. 日内会誌 92: 2035-2038, 2003.

13) Katada A, Kishibe K, Nozawa $H$, et al. : A case report of Wegener's granulomatosis with hypertrophic pachymeningitis. Pract Otol (Kyoto) 95: 1101-1106, 2002.

14）臼㴊 肇, 児玉 梢, 滝沢克己, 他 : 顔面神経麻痺を来し た MPO-ANCA 陽性の中耳炎 2 症例. 日耳鼻会誌 113：6771, 2010.
1) Department of Otolaryngology, Hiratsukakyousai Hospital

2) Department of Otolaryngology, Head and Neck Surgery, Yokohama City University School of Medicine
Corresponding Author Address : Yoshihiro Chiba

chiba_y@yokohama-cu.ac.jp 


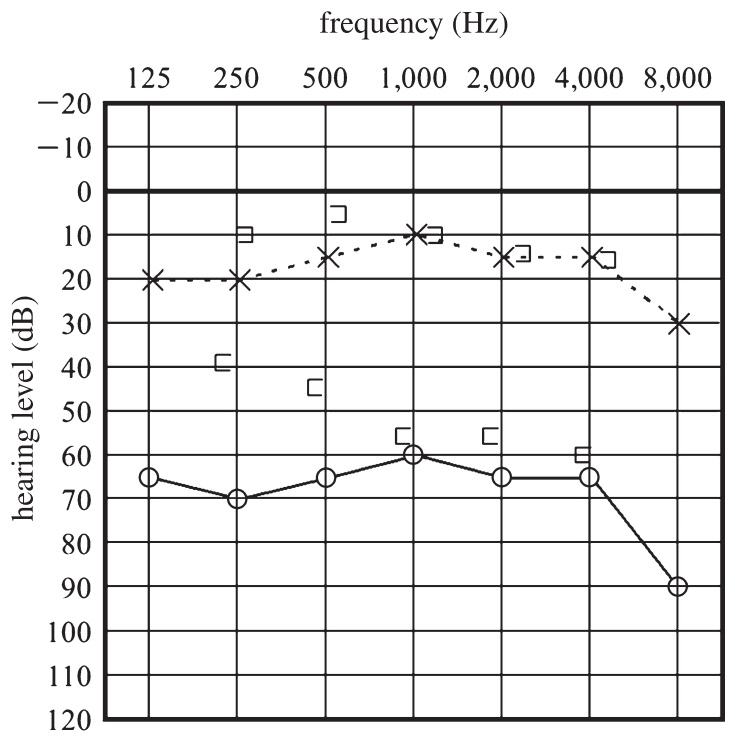

Pure tone audiometry shows mixed hearing loss in the right ear.

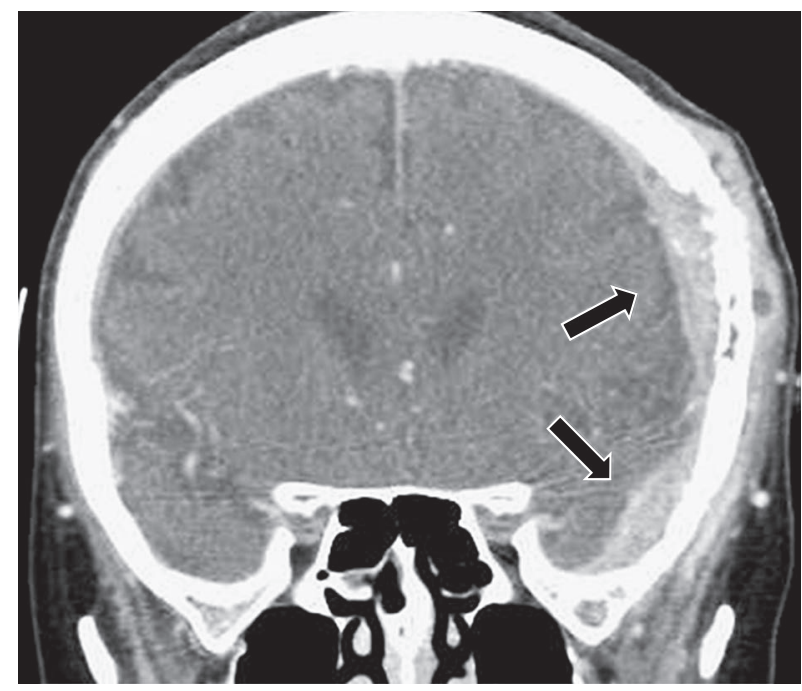

A protruding lesion with enhancement can be observed in the left temporal and occipital fossa, accompanied by external infiltration in the cranial bone.
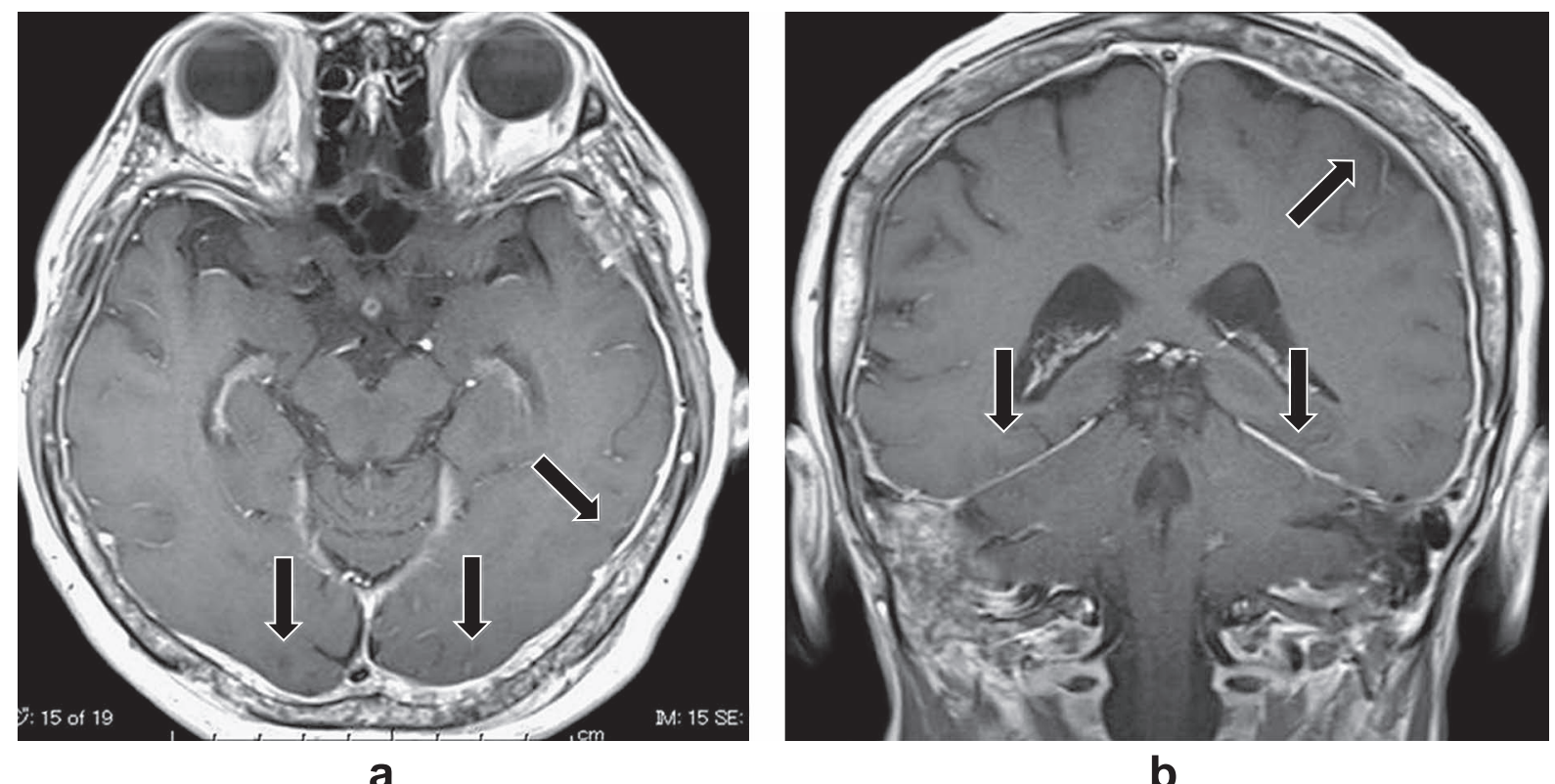

(a: axial section, b: coronal section) Ga-DTPA-enhanced T1 weighed MRI visualizes diffuse hypertrophy in the dura mater, in particular in the left temporal bone. 